\title{
Alternative Way for Determination of Yields Stress as Rheology Parameter for Mudflow
}

\author{
Budijanto Widjaja, Dianita Andriani, Rizka A. Sutisna, and Aglentia Dwi Fitri
}

\begin{abstract}
To understand the behavior of mudflow as one of notorious mass movement in geotechnical engineering, two rheology parameters should be obtained as yield stress and viscosity. Water content for mudflow could be equal to or higher than liquid limit. Viscosity could be obtained using a flow box test. Flow box test uses couple theory from Terzaghi's trap door and Bingham model. There is a limitation for flow box test that it needs yield stress (i.e., undrained cohesion) value for deriving viscosity. Hence, fall cone penetration test could be used to determine yield stress by using the empirical equation based on its penetration. This test uses $80 \mathrm{~g}$ of cone with $30^{\circ}$ cone angle. In this paper, the authors use kaolin, bentonite, Parakan Muncang, and Cipali. The range of water content of each soil is from plastic limit and over liquid limit. The results show that the shear strength of kaolin and Parakan Muncang is higher than bentonite and Cipali. This may due to the type of soil mineral. Hence, the viscosity derived from flow box test show the same results that the viscosity of kaolin and Parakan Muncang is higher than two other soils. All of the viscosities are in the range of published viscosity database. Hence, fall cone penetration test could be used to determine yield stress as rheology parameter for mudflow.
\end{abstract}

Keywords-mudflow, liquid limit, undrained shear strength, fall cone penetration

\section{Introduction}

Research on mudflow is interesting. Mudflow is one of the mass movements that mainly contain fine-grained soil. Its water content $(w)$ is equal to or higher than the liquid limit (LL). This kind of mass movement mostly occurs in Indonesia, Taiwan and the United States. This study examines mudflow behavior to determine rheology parameters. As mudflow is in a viscous liquid state, rheology is a suitable tool to explain its behavior. In this study, the parameters used are yield stress and viscosity. Its limitation is obtaining yield stress using a fall cone penetrometer.

This study aims to present an alternative way of determining yield stress as a rheology parameter for mudflow, to compare the undrained shear strength results from the fall cone penetration test (FCT) and the vane shear test (VST), and to compare the remolded undrained shear strength for both non-expansive and expansive soils.

Budijanto Widjaja, Dianita Andriani, Rizka A. Sutisna, and Aglentia Dwifitri Department of Civil Engineering, Parahyangan Catholic University Indonesia

\section{Literature Review}

Mudflow is a notorious mass movement that flows in a viscous liquid state (i.e., $\mathrm{w} \geq \mathrm{LL}$ ). Mudflow consists of more than $50 \%$ fine-grained soil. Using a conventional constitutive law (e.g., Mohr-Coulomb) to describe the rule of flow for the transportation of mudflow is difficult. Therefore, the rheology approach is introduced.

Rheology is the law of how materials flow. Materials are grouped into two: Newtonian and non-Newtonian materials. Two rheology parameters are used, namely, yield stress and viscosity. For Newtonian materials, yield stress is null. For non-Newtonian materials, behavior is governed by two parameters. Mudflow is considered a non-Newtonian material.

If the shear stress is lower than the yield stress, then no flow occurs. However, if the shear stress is higher than the yield stress, flow occurs and its behavior is dictated by its viscosity. Therefore, viscosity may be a resistant measurement to flow.

The flow box test is a laboratory test used to measure the viscosity of mudflow (Widjaja and Lee, 2013). However, this test requires yield stress (similar to undrained shear strength) as an input parameter to derive the viscosity. As previously mentioned, water content can be higher than the LL (i.e., very soft soils). Undrained soil strength is very low, and a conventional laboratory test is difficult to conduct in the viscous liquid state. To measure its strength, the authors applied the FCT, which obtains the LL through cone penetration. This study used $80 \mathrm{~g}$ of cone with a $30^{\circ}$ cone angle.

The flow box test was derived using Terzaghi trap door theory and the Bingham model. The Bingham model is a simplified rheology model that can effectively simulate the transportation of mudflow.

\section{Method}

Table 1 presents the soil parameters. Kaolin and Parakan Muncang are non-expansive soil, whereas Bentonite and Karang Mukti are expansive soil. The mineralogies of both groups were investigated by X-ray diffraction test. The desired water contents ranged from the plastic limit (PL) to the LL. The water content was obtained using the FCT.

From the FCT, the remolded undrained shear strength $\left(c_{u}\right)$ can be obtained using Houlsby (1982), as in (1). 
Proc. of the Third Intl. Conf. on Advances in Civil and Structural Engineering - CSE 2015

Copyright (C) Institute of Research Engineers and Doctors, USA .All rights reserved.

ISBN: 978-1-63248-057-6 doi: 10.15224/ 978-1-63248-057-6-45

TABLE I. SOIL BASIC PARAMETERS

\begin{tabular}{|c|c|c|c|c|c|}
\hline No. & Sample & $\boldsymbol{L L}$ & $\boldsymbol{P L}$ & $\boldsymbol{G}_{\boldsymbol{s}}$ & Soil type \\
\hline 1 & Kaolin & 68 & 38 & 2.61 & MH \\
\hline 2 & Parakan Muncang & 67 & 29 & 2.60 & $\mathrm{CH}$ \\
\hline 3 & Bentonite & 208 & 115 & 2.67 & $\mathrm{CH}$ \\
\hline 4 & Karang Mukti & 56 & 29 & 2.71 & $\mathrm{MH}$ \\
\hline
\end{tabular}

$$
c_{u}=k \frac{m g}{d^{2}} .
$$

where $c_{u}$ is the remolded undrained shear strength $(\mathrm{kPa}), \mathrm{m}$ is the cone weight $(80 \mathrm{~g}), g$ is the gravity acceleration $(9.81$ $\left.\mathrm{m} / \mathrm{s}^{2}\right), d$ is the penetration depth $(\mathrm{mm})$, and $k$ is the constant that depends on the cone angle. For the cone with the $30^{\circ}$ cone angle and $80 \mathrm{~g}$ weight, $k$ is 1.33 (Koumoto and Houlsby, 2001). O'Brien and Julien (1988) suggested the use of $c_{u}$ as the yield stress for mudflow.

\section{Results and Discussion}

Fig. 1 shows the comparison results between the fall cone penetrometer and the VST for Kaolin. The sample for the VST has a $90 \mathrm{~cm}$ height and a $60 \mathrm{~cm}$ diameter (Widjaja and Setiabudi, 2014). The diameter is $9.9 \mathrm{~cm}$ (rectangular type) and $7.3 \mathrm{~cm}$ (tapered type), with a height-to-diameter ratio of 2.

The trend shows that increased water content is followed by the reduction of undrained shear strength. The undrained shear strength of the fall cone penetrometer and that of the VST are relatively close to each other. The trend is similar to that in Sharma and Bora (2003).

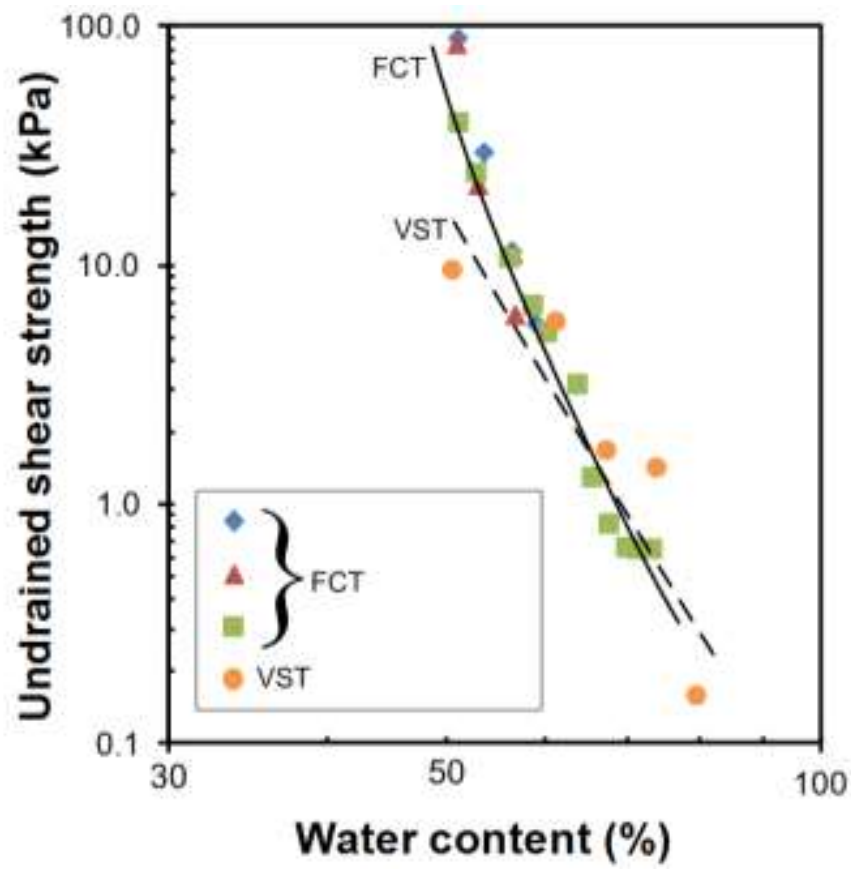

Figure 1. Relationship between water content and undrained shear strength for the fall cone penetration test (FCT) and the vane shear test (VST).
For Parakan Muncang, the trend is similar to that for Kaolin, as shown in Fig. 2. The range of water content for Kaolin is $50 \%-70 \%$ and $50 \%-82 \%$ for Parakan Muncang. Their undrained shear strengths are in the range of $0.6 \mathrm{kPa}-90$ $\mathrm{kPa}$.

Parakan Muncang and Kaolin have an LL of 67 and 68, respectively, with $c_{u}$ of $2 \mathrm{kPa}$. This value indicates that the remolded undrained shear strength at LL is $2 \mathrm{kPa}$.

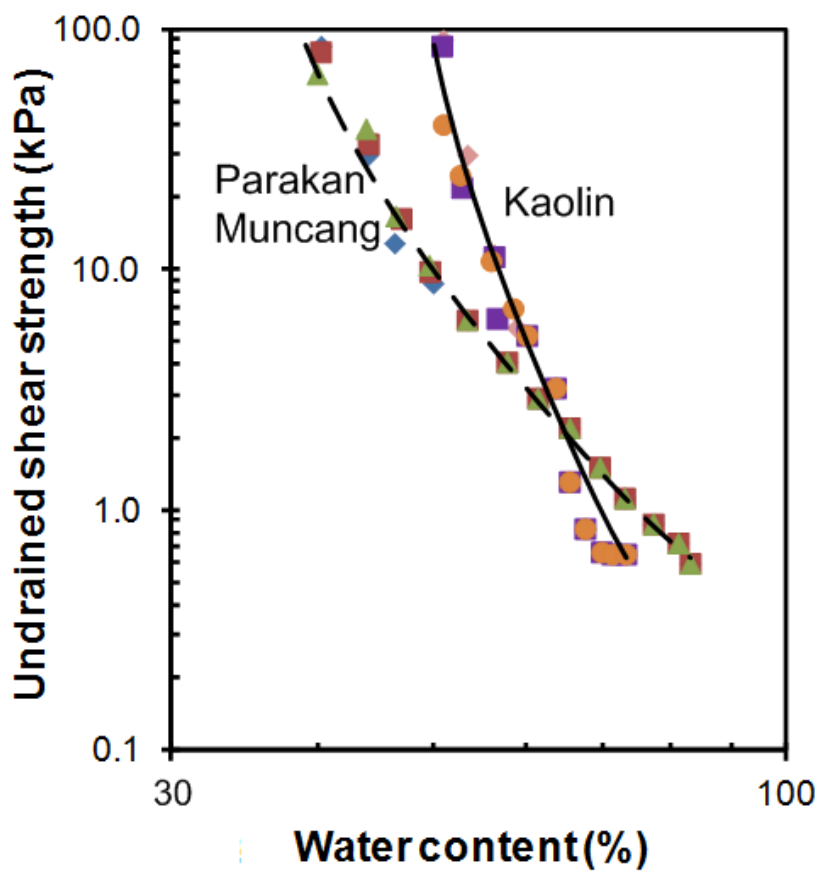

Figure 2. Remolded undrained shear strength for Kaolin and Parakan Muncang using FCT

Figure 3 shows that the range of water content for Karang Mukti is lower than that for Bentonite. However, if the water content is similar to its LL, then the undrained shear strength for Karang Mukti and Bentonite becomes $1.8 \mathrm{kPa}$ and $2.6 \mathrm{kPa}$, respectively, based on the results in Table I.

The undrained shear strength at the LL of all soils is in the range of $1.8 \mathrm{kPa}-2.6 \mathrm{kPa}$. These results are close to those of Casagrande (1932). However, the other interesting result is that the relationship between penetration $(d)$ from FCT and $c_{u}$ is linear for both logarithmic scales. As shown in Fig. 4, the undrained shear strength of all soils is $2.5 \mathrm{kPa}$ for $20 \mathrm{~mm}$ penetration of the cone.

Viscosity $(\eta)$ in the flow box test using yield stress (or $c_{u}$ ) from the FCT for Karang Mukti is in the range of $0.09 \mathrm{~Pa} \bullet \mathrm{s}-5$ $\mathrm{Pa} \cdot \mathrm{s}$, as shown in Fig. 5. The $\eta$ of Bentonite (0.02 Pa $\bullet-0.6$ $\mathrm{Pa} \bullet \mathrm{s})$ is lower than that of Karang Mukti. The reason for this finding is that the yield stress for Bentonite is lower than that for Karang Mukti, and that viscosity in the flow box test is a function of yield stress. Bentonite viscosity is close to 
Maokong viscosity (purple curve in Fig. 5). Maokong is one of the non-expansive soils and is classified as $\mathrm{MH}$.

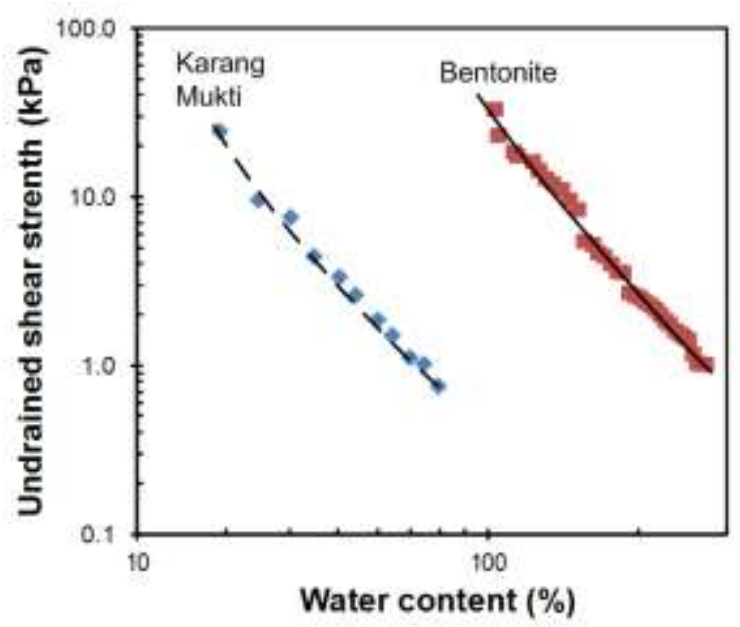

Figure 3. Remolded undrained shear strength for Bentonite and Karang Mukti using the fall cone penetration test.

Among the four samples of this study, Bentonite has the lowest viscosity and Kaolin has the highest. All the viscosity values are in the range similar to that in Widjaja and Lee (2013). Therefore, yield stress can be obtained using the FCT for mudflow.

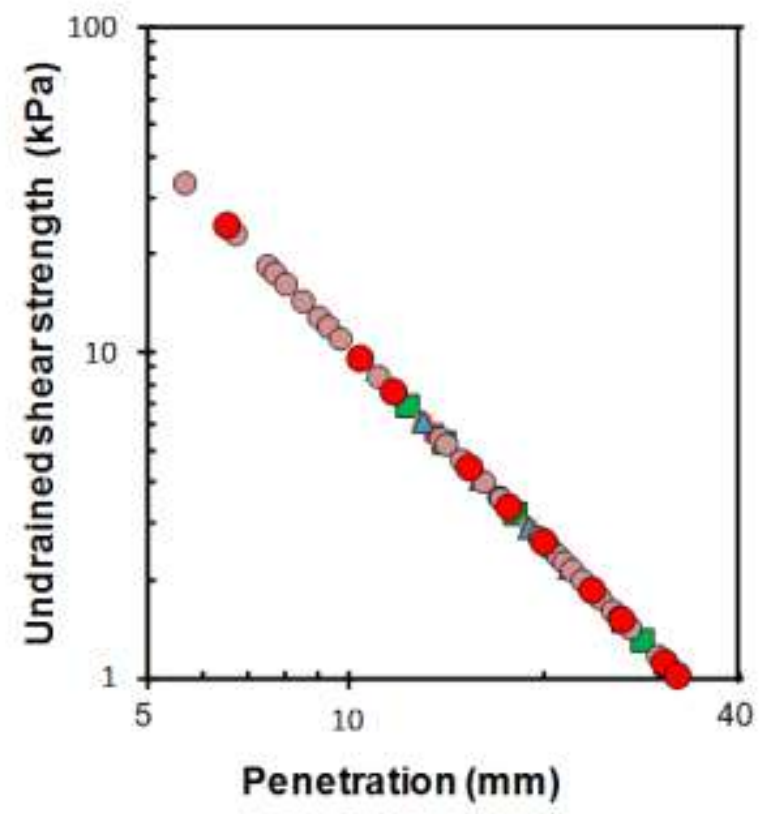

Figure 4. Linear relationship among all soils in this research.

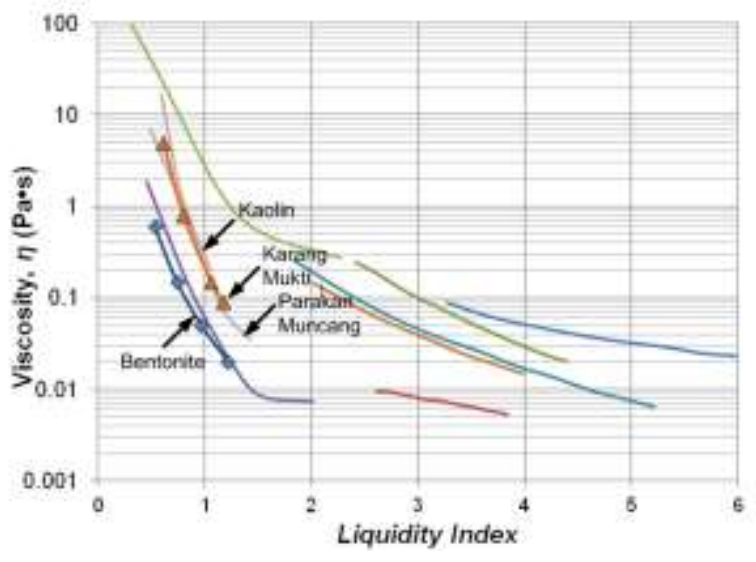

Figure 5. Comparison between the results and those in the published viscosity database.

\section{v. Conclusion}

Obtaining the yield stress (or remolded undrained shear strength) of mudflow is difficult because its strength is very low and it is in a viscous liquid state. This study uses two groups of soil: non-expansive soil (Kaolin and Parakan Muncang) and expansive soil (Bentonite and Karang Mukti). In general, the strength of non-expansive soil is higher than that of expansive soil because of its mineralogy.

The relationship between FCT and VST for Kaolin soil is in very close. The relationship between penetration and undrained shear strength is linear in both logarithmic scales. Therefore, for the two groups of soils, the undrained shear strength is $2.5 \mathrm{kPa}$ using the fall cone penetrometer.

The result of viscosity in the flow box test using the yield stress derived from fall cone penetrometer is similar in range to that of a previous research database. Therefore, the yield stress obtained from the FCT can be used as an alternative way to determine the rheology parameters related to mudflow.

\section{References}

[1] A. Casagrande, " Research on the Atterberg limits of Soils," Public Roads. 13(8), pp. $121-130,1932$.

[2] G.T. Houlsby, "Theoretical analysis of the fall cone test," Geotechnique Vol. 38(3), pp. 433-438, 1982.

[3] T. Koumoto and G.T. Houlsby, "Theory and practice of the fall cone test," Geotechnique 51, No. 8, pp. 701-712, 2001.

[4] J.S. O'Brien and P.Y. Julien, "Laboratory analysis of mudflow properties, “J. Hydraul. Eng., 114(8), pp. 877-887, 1988.

[5] B. Sharma and P.K. Bora, "Plastic limit, liquid limit and undrained shear strength of soil - reappraisal," J. of Geotechnical and Geoenvironmental Engineering, pp. $774-777,2001$.

[6] B. Widjaja dan S.H.H. Lee, "Flow box test for viscosity of soils in plastic and viscous liquid state," Soils and Foundations Vol. 53 No. 1, pp. 35-46, 2013.

[7] B. Widjaja and D.W. Setiabudi, "Obtaining reology parameter using vane shear test for elucidating transportation of mudflow," (in Indonesian), Development of Geotechnical Engineering in Civil Works and Geo-Environment, Yogyakarta, pp. 31-37, June 2014. 
Proc. of the Third Intl. Conf. on Advances in Civil and Structural Engineering - CSE 2015

Copyright (C) Institute of Research Engineers and Doctors, USA .All rights reserved.

ISBN: 978-1-63248-057-6 doi: 10.15224/ 978-1-63248-057-6-45

About Author (s):

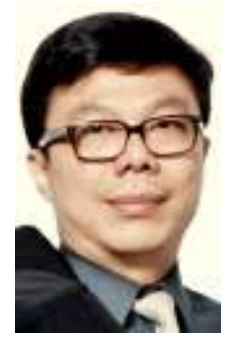

Budijanto Widjaja, Ph.D, has taught soil mechanics and geotechnical engineering at Parahyangan Catholic University, Indonesia. His research interesting is behavior of mudflow (especially in Indonesia and Taiwan), landslides, clayshales, and numerical methods in geotechnical engineering. Nowadays, he is a director of a center for geo-hazards (C4GH). He also got some achievement in mudflow transportation behavior as researcher and best presenter in Taiwan and Indoensia. 